Dhaka Univ. J. Biol. Sci. 21(1): 97-104, 2012 (January)

\title{
NUTRITIONAL QUALITIES OF HILSHA AND SARPUNTI IN DIFFERENT SALT CURING METHODS
}

\author{
Md. Ghulam Mustafa*, Sayeda Rezwana Begum, Md. Abdul Khaleque ${ }^{1}$, \\ MeshKatul Jannat and Dewan Ali Ahsan \\ Department of Fisheries, University of Dhaka, Dhaka-1000, Bangladesh
}

Key words: Nutritional qualities, Salting methods, Hilsha, Sarpunti

\begin{abstract}
Qualities of different salt curing methods such as pickle, mixed, dry and brine salting were assessed in respect of biochemical composition in hilsha and sarpunti. In hilsha, protein, fat and calcium (Ca) contents were slightly higher in laboratory salted products than that of commercial one and phosphorous $(\mathrm{P})$ and iron (Fe) were more or less similar in both laboratory and commercial cases. In sarpunti protein, fat, $\mathrm{P}$ and Fe contents were more or less similar both in laboratory and commercially salted products but Ca content is significantly higher in four types of laboratory products than those of commercial one. Among the four salted products of hilsha and sarpunti, the protein (36.24 \pm 0.58 and $34.04 \pm 0.62 \%)$, fat $(6.81 \pm 0.34$ and $11.34 \pm 0.60 \%), \mathrm{Ca}(114.45 \pm 1.45$ and $444.13 \pm 0.83 \mathrm{mg} / 100 \mathrm{~g}$ fish $), \mathrm{P}(193 \pm 1.40$ and $124.09 \pm 1.37 \mathrm{mg} / 100 \mathrm{~g}$ fish $)$ and $\mathrm{Fe}$ $(1.37 \pm 0.13$ and $2.19 \pm 0.27 \mathrm{mg} / 100 \mathrm{~g}$ fish) were found. Contents were the highest in mixed salted products. Moreover, for producing the finished products dry salting required the least time (5 days in hilsha and 10 days in sarpunti). However, on the basis of the quality and performance, the suitability of four salting methods can be arranged as follows: mixed $>$ dry $>$ pickle $>$ brine.
\end{abstract}

\section{Introduction}

In the agriculture based economy of Bangladesh, fishes and fisheries play an important role in human nutrition, employment, income generation and export earnings. Fisheries provide $63 \%$ of animal protein and contributed 3.74\% GDP and $4.04 \%$ foreign exchange earnings in $2007-2008^{(1)}$. Fish is a highly perishable food item; its rate of deterioration is very rapid, especially at prevailing air temperatures in tropical countries. In many developing countries with tropical ambient temperature, quality deterioration and significant post-harvest losses occur because of inadequate use of ice, long supply chains, poor access to roads and electricity, and inadequate infrastructure and services in physical markets ${ }^{(2)}$.

The marketing infrastructure in Bangladesh including cold storage, freezing, insulated transport facilities, landing centres and wholesale markets is generally inadequate, unhygienic and in disrepair ${ }^{(3)}$. Major fishing grounds are far away from the

*Corresponding author. <mgmustafabd@yahoo.com>.

${ }^{1}$ IFST, BCSIR Laboratories, Dhaka, Bangladesh. 
cities and the consuming centres which are not easily accessible. The time required to reach the destination varies widely according to location. To reach the distant urban centres from fishing grounds, sometimes it takes 7 - 9 days after harvesting which is less than the normal shelf life of many tropical species even if the condition of handling and storing is ideal ${ }^{(4)}$. Fishing is also seasonal.

Salting and drying are the most common methods of fish preservation. In many developing countries like Bangladesh dried salted fish is an important source of low-cost dietary protein ${ }^{(5)}$. Moreover, salted and dehydrated fish is one of the most important export items in Bangladesh. According to $\mathrm{DoF}^{(1)}$, the quantity of exported salted and dehydrated fish products was 658 tons which valued Taka 26.97 crores in 2007 - 2008.

Salt curing of fish is a traditional process used mainly by the marginal fishermen to obtain a product with a tender consistency, pleasant aroma and taste as a result of enzymic activity on the fish flesh. Despite the development of other sophisticated methods, it continues to enjoy popularity in many developing and underdeveloped countries owing to its simplicity and low cost of processing and preservation ${ }^{(6)}$. It is assumed that the curing by salting evolved during heavy catch in places where no other preservation techniques except sun drying were available. Sun drying is difficult during continuous spell of rain-particularly in the sub-tropical zones. In addition, sun drying is not suitable for fatty fishes due to rapid development of rancidity on being exposed to the sun. Therefore, salting is the only available method to preserve fish(7).

Hilsha fish is a very popular and tasty fish among Bangladeshi people living at home and abroad. From the time immemorial, hilsha fishes play very important role in the field of national economic development, employment and in the supply of protein enrich food to the people of Bangladesh. Hilsha fish alone contributes about $12-13 \%$ of the total fish production of Bangladesh and it also contributes about 1\% to the GDP. In 2007 - 2008, total hilsha production was 290,000 metric tons and exported chilled hilsha product was 2,647 metric tons which was worth about Taka 75.45 crores $^{(1)}$. Moreover from the nutritional point of view hilsha fish is considered as a good source of protein, fat and minerals. The fish contains special type of fat having about $50 \%$ of unsaturated fatty acids out of which about $2 \%$ are $w-3$ fatty acids. These fatty acids reduce the human blood cholesterol level thereby reducing the level of heart diseases ${ }^{(8)}$. Hilsha fish protein also contains nine different types of fatty acids which human stomach cannot synthesize. Moreover, it contains higher quality of Ca, P, Fe and vitamin A, D including trace level of vitamin $\mathrm{B}$. Hilsha fish liver contains $120 \mathrm{IU}$ of vitamin $\mathrm{A}^{(9)}$.

Hilsha fishes are often processed by salt curing. Hilsha is too oily for drying. The salted hilsha is locally known as 'nona ilish'. Most consumers favour the product for its characteristic flavour and taste ${ }^{(10)}$. On the other hand sarpunti (Puntius sarana) is a tasty, popular and favorite table fish among the barb species having high nutritional and market value in Bangladesh as well as other Asian countries ${ }^{(9)}$. Sarpunti fishes are also 
salted commercially for preserving long time. But some problems associated with the production of commercially salt cured hilsha and sarpunti fishes do not allow these fish products to be of standard quality. Therefore, the present study was undertaken with a view to taking an attempt for producing better quality salt cured hilsha and sarpunti fish in the laboratory to find out the best method of salt curing for these two fishes and to observe the quality of the salt cured experimental fishes as well as of commercially salt cured fishes collected from the local fish markets.

\section{Materials and Methods}

The fresh as well as commercially salted hilsha (Hilsha ilisha, Hamilton-Buchanan, 1976) and sarpunti (Puntius sarana, Hamilton-Buchanan 1822) fishes were collected from New market of Dhaka city, Bangladesh in their highly acceptable conditions. The raw fishes were eviscerated, cleaned, washed, weighed and prepared for salting in different methods. Four different salting methods such as dry, pickle, mixed and brine salting were adopted.

The raw fishes were enrolled by dry salt (fish weight : salt weight $=3: 1$ ), stacked in containers and stored for a salting or curing period, at room temperature. Then the extracted water of the fishes due to salt action was removed from the container. Thus the fishes were always allowed to remain in dry condition for the production of dry salt cured fish.

The raw fishes were pickle salted as dry salting. But the extracted water was not removed from the container. Thus the fishes were always allowed to remain in salt solution for the production of pickle-cured fish.

During brine salting method, the raw fishes were kept in $30 \%$ saturated brine solution and stacked in containers and stored for a salting or curing period, at room temperature for the production of brine salted fish.

Mixed salting method is a combined form of dry-salting and brine-salting method.

All types of salting were applied in case of hilsa and sarputi for 8 and 2 days, respectively.

The moisture content of the raw and salt-cured fishes was determined by AOAC $\operatorname{method}^{(10)}$. The crude protein of the fish was determined by Micro-Kjedhal method(10) using a factor of $6.25^{(11)}$. For fat determination, the method of Bligh and Dyer ${ }^{(12)}$ was followed. Salt content of the salt-cured fish products was estimated by Mohor method ${ }^{(13)}$. Calcium (Ca) and iron (Fe) were determined by titration method of Vogel ${ }^{(14)}$. Determination of phosphorous $(\mathrm{P})$ was carried out following the NIN Manual ${ }^{(15)}$.

In the present study, the period required for attaining more or less constant weight of the processed fish sample during application of different salt curing methods was considered for determining the performance of the finished processed product. 


\section{Results and Discussion}

Result of biochemical composition including three minerals that were $\mathrm{Ca}, \mathrm{P}, \mathrm{Fe}$ of fresh and different salt cured hilsha and sarpunti are presented in Tables 1 and 2, respectively.

The average moisture (\%), protein (\%), fat (\%) and ash (\%) contents of fresh hilsha were $69.36 \pm 0.71,19.56 \pm 0.44,9.49 \pm 0.54$ and $2.27 \pm 0.16$ (Table-1). These findings were more or less similar with other studies ${ }^{(16,17)}$ with a little variation. In the present study the variation in the proximate composition of the hilsha fish in raw condition was probably due to variations in age, size and environment i.e. location. According to Rubbi ${ }^{(18)}$ and Khuda ${ }^{(19)}$ the quality of commercial fish species changes with the changing of physical characteristics and chemical composition of fishes, which further vary with species, state of maturity, age and size.

The present findings in respect of mineral composition of the fresh hilsha fish correlated with the findings of Thilsted et al.(20). and Banu et al.(21). There was no consistent relationship between the size of a fish and the mineral contents of its musculature. Some species showed wide variation but in others the mineral composition was seen to be uniform regardless of species, size, season or fishing grounds ${ }^{(21-24)}$.

In raw sarpunti, the average moisture, protein, fat, and ash contents were $71.39 \pm$ $0.61 \%, 16.73 \pm 0.92 \%, 9.0 \pm 1.09 \%$ and $2.02 \pm 0.24 \%$, respectively. Similar variation in proximate composition was also observed by Gopalan ${ }^{(25)}$ and CSIR(26). The $\mathrm{Ca}, \mathrm{P}$ and Fe contents $(\mathrm{mg} / 100 \mathrm{~g}$ fish) were $222.68 \pm 1.58,121.81 \pm 1.22$ and $0.42 \pm 0.07$, respectively which were almost similar to the report of CSIR(26).

It was observed that except the moisture content the other nutrients was higher in salted products than that of fresh ones. The moisture contents decreased significantly $(\mathrm{p}<$ 0.05 ) from fresh fish to salted fish (Tables 1 and 2). Because during salting, moisture was rapidly removed from the fish as well as salt penetrated in to the flesh ${ }^{(27)}$.

The protein contents were also increased significantly in salted fish products than that of fresh ones. This might be due to the denaturation of proteins, increase of free amino acids and other forms of non-proteinous nitrogen in the muscle tissue of the fish. On the other hand, in hilsha fish, the fat content decreased significantly after salting but in sarpunti, it was more or less similar in fresh and salted form. This was probably related to the fat content in fresh fish. As hilsha is a fatty fish, after salting a significant amount of fat may be leached out in the self-brine ${ }^{(19)}$. The ash and salt contents increased significantly after salting (Tables 1 and 2). The increase in salt and ash were accompanied by the loss in moisture.

The average moisture content of market samples in both fishes was higher than the laboratory-prepared product which correlated with the findings of Majumdar et al(7). In hilsha, the protein, fat and Ca contents were slightly higher in laboratory salted fish than 


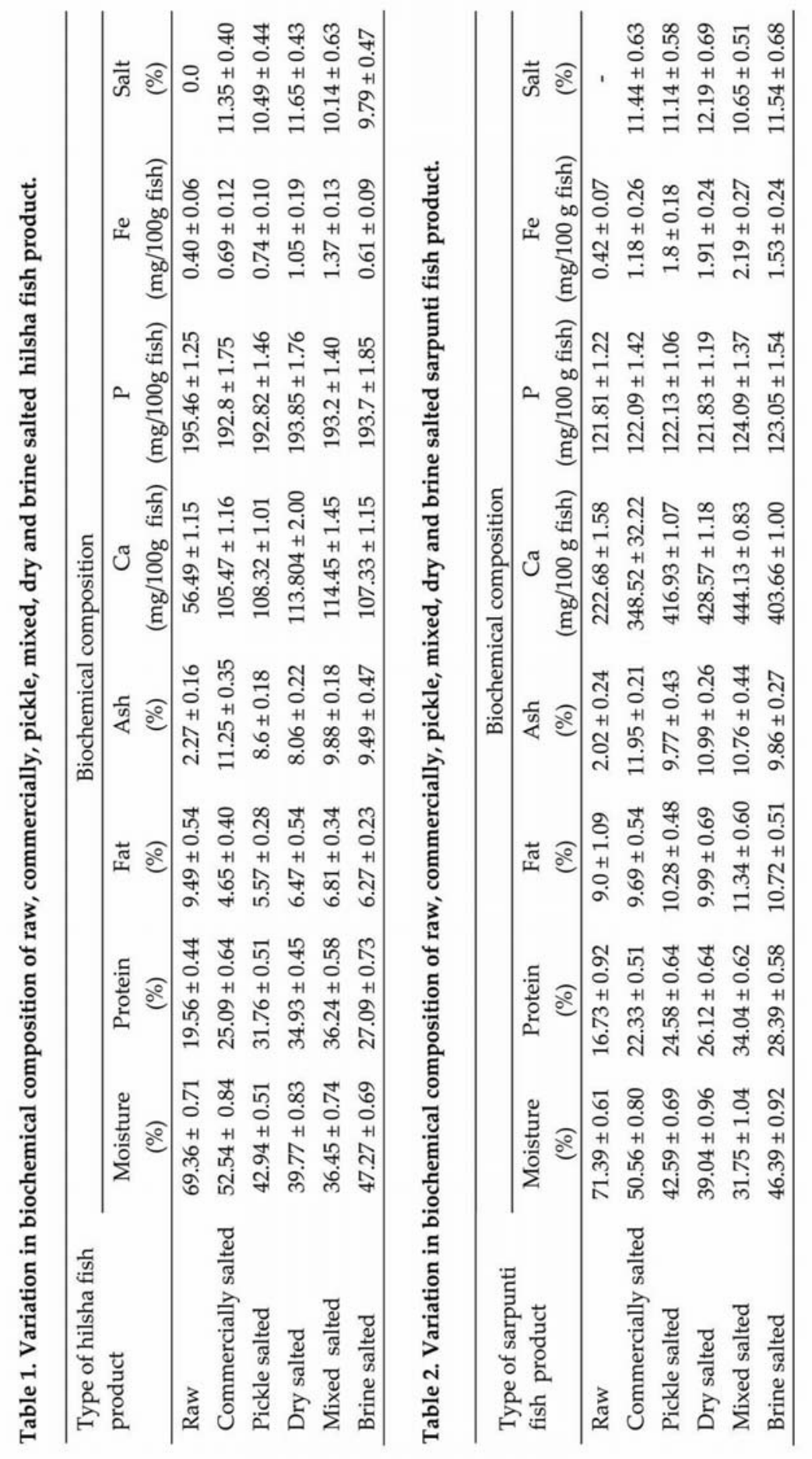


that of commercially salted product (Table 1) whereas, P and Fe contents were more or less similar in both laboratory and commercially prepared salted hilsha. On the other hand, i.e. sarpunti, the protein, fat, $\mathrm{P}$ and Fe contents were more or less similar in both laboratory and commercial scale whereas Ca content was significantly higher in salted products prepared in laboratory (Table 2).

Some variations in biochemical composition were also observed among different salt curing methods though they were not significant in most cases. Among the four salt curing methods of hilsha and sarpunti, the protein (36.24 \pm 0.58 and $34.04 \pm 0.62 \%)$, fat (6.81 \pm 0.34 and $11.34 \pm 0.60 \%), \mathrm{Ca}(114.45 \pm 1.45$ and $444.13 \pm 0.83 \mathrm{mg} / 100 \mathrm{~g}$ fish), $\mathrm{P}(193.2$ \pm 1.40 and $124.09 \pm 1.37 \mathrm{mg} / 100 \mathrm{~g}$ fish $)$, and Fe $(1.37 \pm 0.13$ and $2.19 \pm 0.27 \mathrm{mg} / 100 \mathrm{~g}$ fish $)$ contents were the highest in mixed salted products. These differences might result from variation in the initial composition of the fresh fish used for salt curing. It may also be possible due to the variation in the handling and processing used in different salt curing methods.

The time required for producing the finished product of four salt curing methods which was considered determining their performances are presented in Figs 1 and 2. In different salt curing methods different period of time were required to produce the finished salt cured fish products in the laboratory. In hilsha, the dry, mixed, pickle and brine salt curing methods needed 5, 10, 25 and 30 days, respectively. On the other hand, in sarpunti the dry, mixed, pickle and brine salt curing methods needed 10, 10, 25 and 30

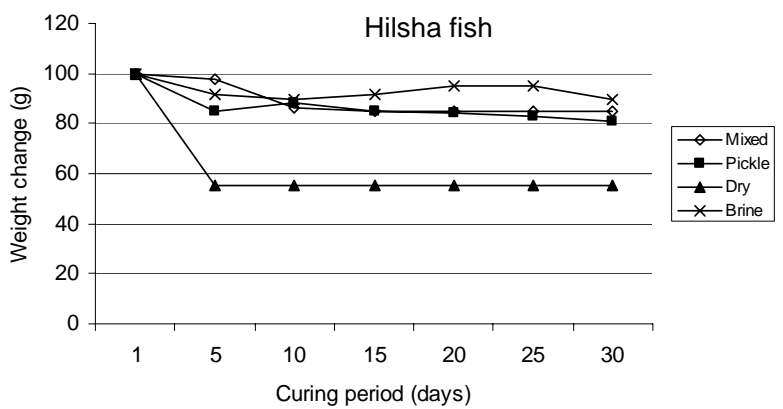

Fig. 1. Line diagram showing the weight change during the period of different method of salt curing of hilsha fish.

days, respectively. In between mixed and dry salting methods, both required same period in sarpunti whereas, in hilsha mixed salting required 5 days more than dry method to attain constant weight. However, by considering both quality and performance, the mixed salting method was found as the best. On the basis of quality and performance the four salting methods can be arranged as follows: Mixed $>$ dry $>$ pickle $>$ brine. 


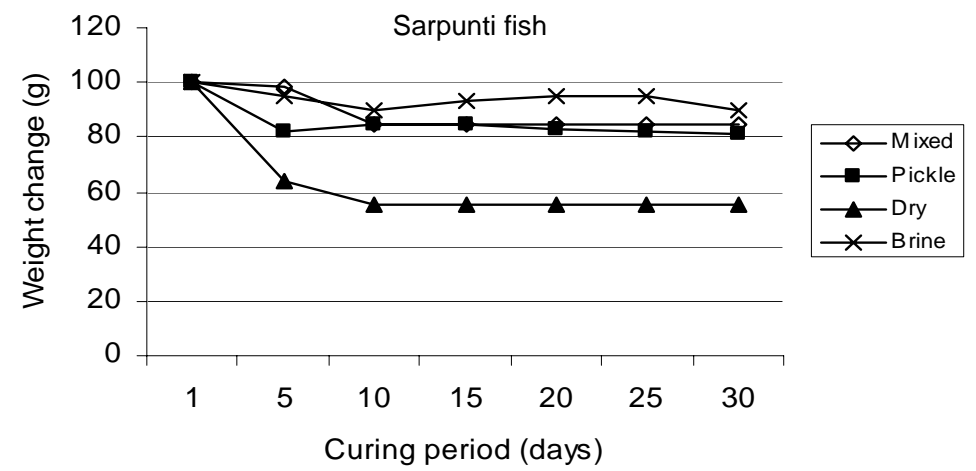

Fig. 2. Line diagram showing the weight change during the period of different method of salt curing of sarpunti fish.

The product prepared in the laboratory was of better quality than the commercially made ones. The market samples were of unknown history and could have been improperly handled during marketing. Therefore, it was not tried to explain any such variation between market samples and laboratory product. Thus the present study provides information about the suitability of different salting methods of two commercially important fishes to produce a very stable and safe product with long storage life. By assessing the nutritional quality as well as the feasibility of the method, it can be recommended to explore the mixed salting method in commercial scale which further will contribute in national economy of Bangladesh.

\section{References}

1. DoF (Department of Fisheries) 2009. Matshapakkha (in Bengali). Department of Fisheries, Dhaka.

2. FAO 1990. Utilization of tropical foods: Animal products. FAO food and nutrition paper 47/8, FAO, Rome.

3. Chowdhury MH 2004. Fish market and marketing issues in Bangladesh. Paper presented at the Twelfth Biennial Conference of the International Institute of Fisheries Economics \& Trade (IIFET), July 20-30, 2004, Tokyo, Japan.

4. Uddin MH and TK Das 1994. Proceedings of the Workshop on Substainable Development of Marine Fisheries Resources in Bangladesh FRI, Cox's Bazar (August 29, 1994) Assistance to Fisheries Research Institute, Bangladesh VRP Sinha, MA Mazid and M. Kamal, Series title: Project reports (not in a Series) - No.7 1994162 pg AC384/E.

5. Bellagha S, A Sahli, A Farhat, N Kechaou and A Glenza 2007. Studies on salting and drying of sardine (Sardinella aurita): Experimental kinetics and modeling. J. Food Eng. 78: 947-952.

6. Wheaton FW and TB Lawson 1985. Other preservation methods. In: Processing Aquatic Food Products. John Wiley and Sons, New York. pp. 273-328.

7. Majumdar RK, S Basu and BB Nayak 2006. Studies on the biochemical changes during fermentation of salt-fermented Indian Shad (Tenualosa ilisha). J. Aqua. Food Product Tech. 15(1): 53-69. 
8. Rao SN, MP Pai, DP Sen and G Mathew 1977. Effect of Sardin oil on the serum cholesterol level. A study in normal human volunteers. The Indian J. Nutr. Diet. 14: 1-7.

9. Chakraborty BK, MI Miah, MJA Mirja and MAB Habib 2006. Induction of gynogenesis in endangered sarpunti, Puntius sarana (Hamilton) and evidence for female homogamety. Aquaculture 258: 312-320.

10. AOAC 1975. Official Methods of Analysis (12th ed.). Association Official Analytical Chemist, Inc., Washington D.C. pp. 836.

11. Pearson D 1970. The chemical analysis of foods. London, J. and A. Churchill, $6^{\text {th }}$ ed.

12. Bligh E and W Dyer 1959. Total lipid extraction and purification. Canadian J. Biochem. Physiol. 37: 911.

13. Alexiyev V 1978. A textbook of quantitative analysis. Foreign language publishing house, Moscow. pp. 379.

14. Vogel AI 1978. Vogel's Textbook of quantitative inorganic Analysis (4th ed.) Longman Group limited, England. pp. 741,787,808.

15. NIN Manual 1976. A manual of laboratory techniques. National Institute of Nutrtition. Indian Council of Medical Research. Hydrabad, India. p. 159.

16. Azam K, MY Ali, M Asaduzzaman, MZ Basher and MM Hossain 2004. Biochemical assessment of selected fresh fish. Dhaka Univ. J. Biol. Sci. 4(1): 9-10.

17. Chandrashekar K and YG Deosthale 1993. Proximate composition, amino acid, mineral, and trace element content of the edible muscle of 20 Indian fish species. J. Food Com. and Ana. 6: 195-200.

18. Rubbi SF 1964. Proximate composition and quality of some commercial species of freshwater fish Bangladesh. J. Sci. Res. 5(1): 1-20.

19. Khuda MQ 1960. Evaluation of the mechanism of fish spoilage by measurement of tyrosine values. Pakistan J. Sci. Ind. Res. 3: 187-190.

20. Thilsted SH, N Ross and N Hassan 1997. The role of small indigenous fish species in food and nutrition security in Bangladesh; ICLARM Quarterly, July-December 1997.

21. Banu C, P Sayeed and Q Salamatullah 1991. Minerals content of freshwater fish and meat. Bangladesh J. Zool. 19(1): 59-63.

22. Love RM 1970. The chemical Biology of fishes. Academic Press. London and New York. p. 265.

23. Stansby ME 1962. Proximate composition of fish. Fish in nutrition. pp. 55-6.

24. Thurston CE 1961. Proximate composition and sodium and potassium contents of four species of commercial bottom fish. J. Food Sci. 26: 495-98.

25. Gopalan C 1978. Nutritive value of Indian foods, National Institute of Nutrition, Indian Council of Medical Research, Hyderabad, India. pp. 64-103.

26. CSIR-India. 1962. Fish and Fisheries. Vol. IV, p. 132.

27. Clucas IJ 1982. Salting of fish: Salt and methods. In: Fish Handling, Preservation and Processing. Part-2. Report of the Tropical Fishery Institute, London. pp. 4-8. 